Biological Science", sera fill a gap in the earlier edition.

The present work certainly marks a great advance on its predecessor; but if it is to develop into a standard work, which may well be, its opening chapter should be rewritten, and more attention paid to detail. In several places the text has been corrected or improved, but other opportunities of doing this have not been taken, notably, the more important of those laxities indicated in a review of the first edition (NATURE 133, 665; 1934). S. J. L.

\section{Philosophy and Psychology}

\section{The Origins of Love and Hate}

By Dr. Ian D. Suttie. Pp. xvi+275. (London : Kegan Paul and Co., Ltd., 1935.) 10s. 6d. net.

Tre late Dr. Suttie may be said to have belonged to the 'eclectic' school of English medical psychologists who, influenced by the teaching of pioneers like Freud, have nevertheless never followed slavishly his metapsychology or bound themselves strictly to his psychotherapeutic technique. Indeed, from the outset Suttie questioned the strict psychoanalytic theory on both logical and biological grounds, and later came to reject its basic explanatory concepts for clinical reasons as well. "The Origins of Love and Hate", however, is not a mere criticism of Freudian theory. It offers an alternative account of the underlying psychical determinants of culture and character (including those of the psychopathological manifestations of the latter) as a constructive contribution to general and abnormal psychology.

The main points on which Suttie differs radically from Freud are his insistence upon the role of the mother rather than the father in the mental development of the child, the substitution of love (in the sense of tender emotion) for libido (in the sexual sense) and for the primal hatred involved in the œdipus situation, and the tracing back of neurotic disorders to their root cause in disturbances of the mother-child relation.

The book will provoke discussion and criticism as indicating a new orientation in genetic psychology.

\section{The World of Colour}

By Dr. David Katz. Translated from the German by Dr. R. B. MacLeod and Dr. C. W. Fox. Pp. xvi +300 . (London: Kegan Paul and Co., Ltd., 1935.) 15s. net.

"The World of Colour" deals with colour perception from the purely psychological, as distinguished from the physiological, point of view ; and, on the basis of experimental work, much of which is highly original in character, offers new solutions of problems of great theoretical and practical interest. Among these the most outstanding are those of the illumination of empty space, the differences of the appearance of colours according to their contexts, and the apparent constancy of colour in varying conditions of lighting. The problem of sensory constancy comprises a series of questions having to do with the stability of perception in general ; and, in the particular case of colours, Katz shows that the way in which we see these in different illuminations approximates in all cases to the 'genuine' colour, which is apprehended in the particular illumination that best reveals the microstructure of the illuminated surface.

While the experimental and theoretical parts of the work will be of the greatest interest to psychologists (incidentally also to physicists, physiologists and even philosophers), the application of the theories made to arts and crafts such as architecture, painting, photography, illuminating technique and the like, will prove to be of no less practical value to the artist and craftsman.

The Attitude of Voltaire to Magic and the Sciences By Dr. Margaret S. Libby. (Studies in History, Economics and Public Law, Edited by the Faculty of Political Science of Columbia University, No. 408.) Pp. 299. (New York : Columbia University Press; London : P. S. King and Son, Ltd., 1935.) 16s. 10d. Is this work, which represents a large amount of research, the originality of Voltaire in the field of the various sciences is rightly shown to be overestimated, though for his skill and importance as a popular exponent of the new scientific ideas, he retains full credit. The views of Voltaire are shown here against a background of the scientific developments of his time. Historians of science and philosophy will thus find in this work ample material for consideration and study. It would remain to be shown, for example, what are the detailed relations between the religious philosophy and the history of science in the eighteenth century.

\section{Philosophy and the Concepts of Modern Science}

By Prof. Oliver L. Reiser. Pp. xvii +323. (New York: The Macmillan Co., 1935.) 15s. net.

THE conclusions of the sciences, often used uncritically, help the author to build up a rather peculiar vision of the universe. Pleading for a revival of anthropomorphism and for a religion of humanism, he lets his mind roam from a justification of a modified emergent evolutionism to that of a generalised sun worship, the gap between the two being bridged by a novel conception of light as the link between logic and physics, mind and brain, the physical and the spiritual. The book, though very readable and interesting, is one link in that extraordinary chain of American works which points to the imminent birth of a now Western wisdom the esoteric meaning of which is understandable, at least at present, to a selected few.

T. G.

\section{The Book of the It :}

Psychoanalytic Letters to a Friend. By Dr. Georg Groddeck. Pp. 301. (London: The C. W. Daniel Co., 1935.) 10s. 6d. net. (Supplied to medical and psychological readers only.)

THIs book consists of letters written by Dr. G. Groddeck to a friend. They are all on a psychoan. alytic basis and consist of advice on a variety of matters relating to sex, family life, ete. To those readers who are acquainted with the psychology of sex and its many and varied manifestations in every- 
day life, this book will present little if anything that is new, but the book is very readable and states the facts of symbolism, etc., in a clear and interesting manner. Those who are not wholehearted Freudians will find much of the book disagreeable and un. acceptable.

\section{$\mathrm{I}$ and $\mathrm{Me}$ :}

a Study of the Self. By E. Graham Howe. Pp. 256. (London: Faber and Faber, Ltd., 1935.) 7s. 6d. net. "I AND ME", which is stated to be a study of the self, consists of six lectures delivered for the Home and School Council of Great Britain in 1934. The author compares the pattern of the teaching contained in these lectures to that presented by Tao, 2,500 years ago. There are a number of diagrams which are well executed but convey little or nothing to the reader, whatever symbolic meaning they may contain for the author. The chapters are devoted to the selves, the family, society, science, medicine and religion.

\section{Technology}

\section{The Chemistry of Cement and Concrete}

By F. M. Lea and Dr. C. H. Desch. Pp. xii $+429+10$ plates. (London: Edward Arnold and Co., 1935.) $25 s$. net.

Few materials of construction are more important than cement-indeed some six million tons are made and used in Britain per annum. The cement works are mostly up to date, and the cost of the finished article is continually being reduced, whilst its quality is satisfying increasingly stringent standards. The chemical knowledge of the subject continues to grow, and it is this aspect that is contained in the present book, which is a considerably extended new edition of the work first written by Dr. Desch in 1911 and now long since out of print.

The chief author is on the staff of the Building Research Station, and thus thoroughly au fait with the more practical aspect of the subject. The scope includes the chemistry of the changes which the raw materials undergo during conversion into elinker and cement, and covers a very wide field including the properties and behaviour in use of concretes even under such varied conditions as in sea-water and in pipes for the transport of effluents.

The book is likely to become the standard work of reference in this field for both chemists and engineers.

\section{Symposium on the Welding of Iron and Steel}

Vol. 1: Present Day Practice and Problems of Welding in the Engineering Industries. Pp. $\mathrm{xx}+$ $676+136$ plates. Vol. 2: Welding Practice and Technique, including Welding Apparatus; the Metallurgy of Welding; Specification, Inspection, Testing and Safety Aspects of Welding. Pp. vii + $974+123$ plates. (London: Iron and Steel Institute, 1935.) 2 vols., $£ 22 s$; to Members, $30 s$.

ON May 2-3, 1935, a symposium on the welding of iron and steel was held by the Iron and Steel Institute in conjunction with a large number of other societies and institutions concerned with this subject. The papers then presented, together with a number received since the meeting, are now available in book form. The number of such contributions has reached the high figure of 150 , of which 84 have come from Great Britain, 14 from the United States, 10 from Australia and 9 each from France and Germany. The present volumes, therefore, may truly be claimed to represent an international effort to indicate the present position of the welding industry and the research work which is being done in connexion with it. It will come as a surprise to many people to learn how widespread welding has become and how important are the parts which are joined together by this means.

In addition to the papers themselves, the volumes contain summaries of each section, the discussions and correspondence on the papers, together with both name and subject indexes. In view of the large amount of material to be presented it has been thought well to subdivide the papers into four groups, of which the first deals with present day practice and problems of welding in the engineering industries, the second, welding practice and technique including apparatus, the third, the metallurgy of welding, and finally, specification, inspection, testing and safety.

The papers contained in these reports form by far the most substantial contribution ever made to scientific and technical advance in the welding industry. Even those concerned solely with the welding of non-ferrous materials will find in the present volumes an enormous amount of information which is directly applicable to their own work.

F. C. T.

\section{Boiler Feed Water Treatment}

By F. J. Matthews. Pp. $256+9$ plates. (London: Hutchinson's Scientific and Technical Publications, n.d.) $12 s, 6 d$.

Tris should prove to be a most useful book. The problem of feed water treatment is a very real one, and a great variety of treatments are now prescribed so that the ordinary operator requires assistance in his choice. The super-pressure boilers require special consideration and treatment, for which skilled chemical assistance is an essential. Water supplies are always changing and periods of drought or excessive rainfall also bring about changes. The author has put together a very readable compendium under the headings of scale formation, corrosion, foaming and priming.

\section{A Textbook of Pharmacognosy}

By J. W. Cooper and T. C. Denston. With Illustra. tions and Drawing Notes by M. Riley and D. W. Shaw. Second edition. Pp. xiii +522. (London: Sir Isaac Pitman and Sons, Ltd., 1935.) 18s. net. IN the second edition of this well-established book, more information of a theoretical nature has been added. Accounts of the geographical distribution, collection and preparation for the market of drugs have also been included. The subject matter is very comprehensive, and satisfies the syllabus in pharma. cognosy for the Chemist and Druggist Qualifying Examination, and to those candidates the book can be earnestly recommended. 